This item was submitted to Loughborough's Research Repository by the author.

Items in Figshare are protected by copyright, with all rights reserved, unless otherwise indicated.

\title{
Job stressors and voluntary work behaviours: mediating effect of emotion and moderating roles of personality and emotional intelligence
}

PLEASE CITE THE PUBLISHED VERSION

http://dx.doi.org/10.1111/1748-8583.12044

\section{PUBLISHER}

(c) John Wiley \& Sons Ltd.

\section{VERSION}

AM (Accepted Manuscript)

\section{PUBLISHER STATEMENT}

This work is made available according to the conditions of the Creative Commons Attribution-NonCommercialNoDerivatives 4.0 International (CC BY-NC-ND 4.0) licence. Full details of this licence are available at: https://creativecommons.org/licenses/by-nc-nd/4.0/

\section{LICENCE}

CC BY-NC-ND 4.0

\section{REPOSITORY RECORD}

Greenidge, Dion, and lain J. Coyne. 2019. "Job Stressors and Voluntary Work Behaviours: Mediating Effect of Emotion and Moderating Roles of Personality and Emotional Intelligence". figshare. https://hdl.handle.net/2134/22465. 


\section{Human Resource \\ Management Journal}

\section{Job Stressors and Voluntary Work Behaviours: Mediating Effect of Emotion and Moderating Roles of Personality and Emotional Intelligence}

\begin{tabular}{|c|l|}
\hline Journal: & Human Resource Management Journal \\
\hline Manuscript ID: & 13 -HRMJ-02359.R2 \\
\hline Wiley - Manuscript type: & Original Article \\
\hline Keywords: & $\begin{array}{l}\text { Emotion, Voluntary work behaviours, Job stressors, Big five personality, } \\
\text { Emotional Intelligence }\end{array}$ \\
& $\begin{array}{l}\text { Framed within an emotion-centred model (Spector and Fox, 2002), the } \\
\text { current study investigated the mediating role of negative and positive } \\
\text { emotion between job stressors and counterproductive work behaviours } \\
\text { (CWB) and citizenship behaviours (OCB) and the moderating effects of } \\
\text { personality and ability-based emotional intelligence (EI) on the } \\
\text { relationships between job stressors and emotions. Results from a sample of } \\
\text { 202 Caribbean employees across eight public and private sector } \\
\text { organizations showed that both positive and negative emotion mediated } \\
\text { the relation between job stressors and citizenship behaviours, whereas } \\
\text { only negative emotion was found to mediate the relation between job } \\
\text { stressors and CWB. Some, support was found for the moderating effects of } \\
\text { personality and emotional intelligence. Implications for research and } \\
\text { practice are discussed. }\end{array}$ \\
\hline Abstractions
\end{tabular}


Job Stressors and Voluntary Work Behaviours: Mediating Effect of Emotion and Moderating Roles of Personality and Emotional Intelligence 


\begin{abstract}
Framed within an emotion-centred model (Spector and Fox, 2002), the current study investigated the mediating role of negative and positive emotion between job stressors and counterproductive work behaviours (CWB) and citizenship behaviours (OCB) and the moderating effects of personality and ability-based emotional intelligence (EI) on the relationships between job stressors and emotions. Results from a sample of 202 Caribbean employees across eight public and private sector organizations showed that both positive and negative emotion mediated the relation between job stressors and citizenship behaviours, whereas only negative emotion was found to mediate the relation between job stressors and CWB. Some, support was found for the moderating effects of personality and emotional intelligence. Implications for research and practice are discussed.
\end{abstract}

Keywords: Emotion; Voluntary Work Behaviours; Job stressors; Big Five personality; Emotional Intelligence 


\section{Introduction}

Organizational citizenship behaviour (OCB) and counterproductive work behaviour (CWB) are typically seen as discretionary, non-task in nature and, coupled with task performance, represent three broad domains of job performance (Rotundo \& Sackett, 2002). In the HR literature, OCB (sometimes termed extra-role behaviour or discretionary work behaviour) has received recent attention (Gong et al., 2010; Frenkel et al., 2012) and is viewed as a HRrelated outcome of HRM (Knies \& Leisink, 2014). Indeed, OCB “...is seen as the critical factor in linking employee responses to performance..." (Purcell \& Hutchinson, 2007: 6). Within the same HR domain, CWB has been considered at the level of specific behaviours such as absenteeism (e.g. Hopkins, 2014) and workplace bullying (e.g. Woodrow \& Guest, 2014) as well as the broader CWB concept (e.g. Chao et al., 2011). In the people management-performance causal chain (Purcell \& Hutchinson, 2007) discretionary behaviour and attendance (a specific form of CWB) coupled with task behaviour are hypothesised to influence organisational effectiveness.

However, although OCB and CWB are important HR-related outcomes of people management, they have tended to be researched in isolation. Yet with consensus that both behaviours can be conceptualised via distinct subgroups of organisationally and individually directed behaviours (Bennett \& Robinson, 2000; Gruys \& Sackett, 2003) researchers have become more interested in the commonality between the two constructs and theoretical explanations for why people engage in them (Dalal, 2005; Spector, \& Fox, 2010). One such theory, Spector and Fox's (2002) emotion-centred model, postulates that an employee's emotional reactions are induced by their appraisal of the work environment and that induced emotion could lead to OCB or CWB. Positive emotion should produce OCB while negative 
emotions should produce CWB. Furthermore, personality and perceived control over work tasks are hypothesized to moderate the relationship between job stressors and emotions. The purpose of our investigation was to develop further some of the proposed relationships in Spector and Fox's model. Specifically, we tested the main mediation propositions of positive and negative emotion as well as including the moderating effects of the Big Five personality traits and abilitybased emotional intelligence (EI). As emotion plays a central role in Spector and Fox's model, we included EI since an individual's ability to understand and regulate their emotions so as to attain desired affective states and adaptive outcomes are particularly relevant (Wong \& Law, 2002). Figure 1 shows the proposed relationships to be tested in this study.

Insert Figure 1 about here

This study constitutes the first effort, to our knowledge, to explore the mediating effect of positive emotion on the relationship between job stressors and citizenship behaviours; and the moderating effects of Big Five personality traits and EI on relations between job stressors and emotions. Moreover, research on the role of emotions, its causes, expression, and consequences in organizational settings are still vastly fragmented and limited (Brief \& Weiss, 2002). Therefore, this study enhances our theoretical understanding of how the work environment, emotion and individual differences combine to influence OCB and CWB. Furthermore, such knowledge would allow HR managers and/or practitioners to better develop appropriate interventions aimed at reducing negative workplace behaviours such as CWB, and enhancing positive workplace behaviours such as OCB. Hence, HR policies and practices could be better directed to achieve more favourable HRM outcomes. 


\section{Theoretical framework}

\section{Emotion and $O C B / C W B$}

Emotion is defined as " adaptive behavioural and physiological response tendencies that are called forth directly by evolutionarily significant situations"' (Gross, 1998, p. 272). Negative emotions are induced if an individual perceives a situation as threatening to his or her well-being while positive emotions are induced if the individual appraises the situation as enhancing wellbeing (Lazarus, 1993). Theoretically, Spector and Fox (2002) argue that emotions lead to action tendencies and intentions to reduce negative and enhance positive states. Induced negative emotion is likely to lead to CWB, either to passively and indirectly cope with the emotion or to actively and directly attack the agent of the situation. Whereas, induced positive emotion is likely to produce OCB since positive states are likely to induce approach tendencies to remain in the situation (Spector \& Fox, 2002).

Empirically, relationships between job stressors and CWB (Miles, Borman, Spector, \& Fox, 2002; Penny \& Spector, 2005) and OCB (Miles et al., 2002), as well as between stressors and negative emotion (Fox, Spector, \& Miles, 2001; Miles et al., 2002) and positive emotion (Fox, et al., 2001) has emerged. However, whilst the relationship between negative emotion and CWB has generated more support (Fox et al., 2001; Miles et al., 2002), limited support is seen between positive emotion and citizenship behaviours (Miles et al. 2002). Studies have found support for the mediating effect of negative emotion between job stressors and CWB (Fox \& Spector, 1999; Fox et al., 2001), but to our knowledge no evidence has emerged supporting the mediating effect of positive emotion between job stressors and OCB. Therefore, we propose: Hypothesis 1: Negative emotion mediates the relationship between job stressors and $C W B$. 
Hypothesis 2: Positive emotion mediates the relationship between job stressors and OCB.

\section{Personality}

Personality influences appraisal of the stressor and emotional reaction to it, as well as determining if emotion leads to OCB and CWB (Spector and Fox, 2002). A great deal of research has used the Big Five model of personality (Emotional Stability, Extraversion, Openness to Experience, Agreeableness, and Conscientiousness) as an organizing framework for investigating the relationship between personality and important variables such as occupational stressors (Bowling \& Eschleman, 2010), and CWB and OCB (Sackett, Berry, Wiemann, \& Laczo, 2006).

To tie the research on the Big Five and the stressor-emotion model together, we adopt Gross' (1998) model of emotional regulation as the theoretical basis for our investigation. Emotional regulation refers to the processes by which individuals affect which emotions they have, when they have them, and how these emotions are experienced and expressed (Gross, 1998). Individuals can regulate emotion response tendencies either by using antecedent-focused regulation strategies, which influence whether or not particular emotions are triggered, or response-focused regulation strategies which influenced how emotions are modulated once they have been triggered (Gross, 1998; John \& Gross, 2007).

Conscientious individuals are more likely to use antecedent-focused emotional regulation strategies (e.g. deploying attention, and cognitive reappraisal) than non-conscientious individuals (John \& Gross, 2007). Gross \& John (2003) reported that Conscientiousness correlated positively with cognitive reappraisal -interpreting a potentially emotion-eliciting situation in a manner that modifies its emotional impact before it occurs. Cognitive reappraisal alters the entire subsequent emotion trajectory, including experiencing more positive emotion and less negative emotion 
(John \& Gross, 2007). Thus, conscientious people are more likely to reappraise stressful events, therefore experiencing low levels of negative emotions and high levels of positive emotions than non-conscientious people. Given this we hypothesized that:

Hypothesis 3: The relationship between job stressors and negative emotion is stronger when Conscientiousness is low, whereas the relationship between job stressors and positive emotion is stronger when Conscientiousness is high.

Individuals high on Neuroticism are anxious, easily frustrated, insecure (Caspi, Roberts, \& Shiner, 2005), and are more vulnerable to daily stressors than those low on this factor (Gunthert, Cohen, \& Armeli, 1999). John and Gross (2007) postulated that Neuroticism should be negatively related to antecedent-focused emotional regulation strategies, suggesting that highly neurotic individuals would engage in fewer, and make less effective attempts at emotion regulation. As Neuroticism correlates negatively with reappraisal (Gross and John, 2003), emotionally stable people are more likely to reappraise stressful events and experience low levels of negative emotions and high levels of positive emotions than non-emotionally stable people. We hypothesized that:

Hypothesis 4: The relationship between job stressors and negative emotion is stronger when Emotional Stability is low, whereas the relationship between job stressors and positive emotion is stronger when Emotion Stability is high.

Extraverts are more likely than introverts to experience positive emotions (Watson \& Clark, 1997) and to express both positive and negative emotions (Gross \& John, 1998).

Extraversion has been found to correlate positively with emotional understanding and regulation (Ciarrochi, Chan, Caputi, 2000) and reappraisal (Gross \& John, 2003). Thus, as extraverts are 
more likely to reappraise stressful events, they experience low levels of negative emotions and high levels of positive emotions than non-extraverts. Our fifth hypothesis is:

Hypothesis 5: The relationship between job stressors and negative emotion is stronger when Extraversion is low, whereas the relationship between job stressors and positive emotion is stronger when Extraversion is high.

Openness to experience is related to greater awareness, clarity, and intensity of whatever emotion the individual is experiencing at a given time. Individuals high on openness should feel optimistic about regulating their emotions; they accept their emotions as real, important, and generally worth attention and regulation (John \& Gross, 2007). People high on Openness to Experience are more likely to reappraise stressful events (Gross and John, 2003); therefore they experience low levels of negative emotions and high levels of positive emotions. Hypothesis six is:

Hypothesis 6: The relationship between job stressors and negative emotion is stronger when openness is low, whereas the relationship between job stressors and positive emotion is stronger when Openness is high.

In terms of regulatory strategies, most effects for Agreeableness would be determined by the specific interpersonal features of the situation (John \& Gross, 2007). Nevertheless, Gross and John (2003) found Agreeableness to be related positively to reappraisal. Thus, people high on agreeableness are more likely to reappraise stressful events and are therefore likely to show low levels of negative emotions and high levels of positive emotions. Given this we hypothesized that: 
Hypothesis 7: The relationship between job stressors and negative emotion is stronger when Agreeableness is low, whereas the relationship between job stressors and positive emotion is stronger when Agreeableness is high.

\section{Emotional Intelligence}

The emotional intelligence literature is proliferated with controversies over its conceptualization and measurement (Davies, Stankov, \& Roberts, 1998) with researchers either adhering to an ability-based (Mayer, Caruso \& Salovey, 1999) or trait-based model (Petrides \& Furnham, 2000). In this study, EI is defined as a set of interrelated skills concerning "the ability to perceive accurately, appraise, and express emotion; the ability to access and/or generate feelings when they facilitate thought; the ability to understand emotion and emotional knowledge; and the ability to regulate emotions to promote emotional and intellectual growth" (Mayer \& Salovey, 1997: 10).

As before, emotional regulation seems to be a reasonable theoretical basis for the proposed moderating effect of EI between job stressors and emotion. Brunetto et al., (2012) argue those low in EI try to control their exposure to negative emotions and when unable to do so, negative performance outcomes are likely to emerge. High EI individuals should to be able to modulate their response tendencies and have more effective emotion regulation processes so as to attain desired affective states (Wong \& Law, 2002). High EI individuals can make effective use of antecedent-focused emotion regulation strategies to produce positive emotion and promote emotional and intellectual growth (Wong \& Law, 2002). Based on this, we hypothesized that:

Hypothesis 8: The relationship between job stressors and negative emotion is stronger when EI is low, whereas the relationship between job stressors and positive emotion is stronger when EI is high. 


\section{Method}

\section{Participants}

The study comprised 202 employees across eight organizations from the manufacturing, financial, and services private industry and the public sector in Barbados. Of the participants, $101(50 \%)$ were male and $101(50 \%)$ were female, mean age of 35 years $(\mathrm{SD}=10.29)$ and mean tenure of 8.6 years $(\mathrm{SD}=8.16)$. Researchers have argued that heterogeneous populations provide more variation in work characteristics and behaviours than homogenous populations and such variation is "more important than representativeness of the sample under study" (De Lange et al., 2003: 287). The majority of the sample was non-manual workers $(56.4 \%)$, with $35.1 \%$ manual workers and $8.4 \%$ in a managerial/supervisory position. Of the employees providing other ratings, $89(44.1 \%)$ were male and $111(55 \%)$ were female. Average age was 35 years (SD = 9.94).

\section{Measures}

Stressors. Work-constraints were measured by the Organizational Constraints Scale (OCS; Spector \& Jex, 1998). The OCS is an 11-item scale indicating how frequently job performance is hindered by constraints such as inadequate training, co-workers, rules and procedures and availability of resources (rating from 1, less than once per month or never, to 5 , several times per day). Spector and Jex (1998) reported a mean Cronbach's $\alpha$ of .85 across eight samples. Interpersonal conflict was measured by the Interpersonal Conflict at Work Scale (ICAWS; Spector \& Jex, 1998). ICAWS is a 4-item scale where participants indicate the frequency of conflict with others at work, ranging from 1 (never) to 5 (Always). Spector and Jex (1998) reported a mean Cronbach's $\alpha$ of .74 across thirteen samples. Role Stressors (role ambiguity and role conflict) were measured by Rizzo, House \& Lirtzman's (1970) 14-item scale. 
Role ambiguity was measured by 6 -items while role conflict is measured by 8 -items. Participants responded to each item on a 7-point Likert scale ranging from 1 (strongly disagree) to 7 (strongly agree). Low scores on the role ambiguity subscale represent high role ambiguity and high scores on the role conflict subscale represent high role conflict.

Emotions. Van Katwyk et al's. (2000) Job-Related Affective Well-being Scale (JAWS) was used to assess a wide range of emotions experienced in response to conditions of the job. Items asked employees to indicate how often they feel each of 30 emotional states by choosing one of five response choices ranging from 1 (almost never) to 5 (extremely often or always). A positive emotion score was obtained by summing scores on the 13 positive affect items; a negative emotion score was obtained by summing the scores on the 17 negative items. Van Katwyk et al. reported a Cronbach's $\alpha$ of .95 for the overall JAWS.

Personality. The Big Five personality dimensions of Conscientiousness, Extraversion, Emotional Stability, Agreeableness and Open to Experience were each measured by 10-item versions of each scale of Goldberg's (1999) Big Five factor markers in the International Item Pool. The construct validity of this scale has been demonstrated in terms of its relationship with the corresponding scales in the NEO (Costa \& McCrae, 1992). Each item was rated on a 5-point Likert scale ranging from 1 (very inaccurate) to 5 (very accurate).

Emotional Intelligence. The Wong and Law Emotional Intelligence Scale (WLEIS, 2002) was used to measure ability-based EI. Previous studies support the scale's factor structure, internal consistency, convergent, and discriminate validity (Law et al., 2004; Wong \& Law, 2002). Moreover, this scale has been shown to measure a construct distinct from Big Five personality (Law et al., 2004; Wong \& Law, 2002). The scale consists of four dimensions with four items in each dimension. The Self-Emotion Appraisal (SEA) dimension relates to 
individuals' ability to understand and express their emotions. The Others' Emotion Appraisal (OEA) dimension relates to individuals' ability to perceive and understand the emotions of others. The Regulation of Emotion (ROE) dimension relates to individuals' ability to regulate their own emotions. The Use of Emotion (UOE) dimension relates to individuals' ability to make use of their own emotions by channelling them toward constructive activities to facilitate performance. Participants responded to each item using a 7-point Likert-type response scale ranging from $1=$ (strongly disagree) to 7 (strongly agree). High scores represented high ability emotional intelligence.

$O C B$ and $C W B$. The 50-item version of the Voluntary Workplace Behaviour Scale (VWB) (see Coyne et al, 2013) was used to measure OCB and CWB. The scale assessed a fivefactor model including interpersonal courtesy (e.g. Treated other employees in the organisation with respect), interpersonal helping (e.g. Given helpful advice to a co-worker), organizational citizenship behaviours towards the organization (OCBO; e.g. Made suggestions to improve the organisation), counterproductive work behaviours towards the organization (CWBO; e.g. Damaged or wasted property, material or company supplies), and counterproductive work behaviours towards the individual (CWBI; e.g. Been rude and offensive to another employee). Other raters were asked to rate the extent that their co-worker engaged in citizenship behaviours and counterproductive work behaviours in the previous 12-months on a six-point Likert scale from ' $0=$ never' to ' $6=$ very often'.

Confirmatory factor analysis (CFA) goodness of fit test statistics provided evidence for the factor structure of the five factor VWB scale $\left(\chi^{2}=202.5, d f=80, p<.001\right.$; RMSEA $=.08$, 
$\mathrm{CFI}=.96, \mathrm{NNFI}=.94)$. Also, CFA was conducted for all other scales in the study and the fit indices showed reasonable and good fit ${ }^{1}$.

\section{Procedure}

Two survey instruments - a self-report questionnaire and peer or co-workers rating measure of VWB and return envelopes were distributed to participants. Employees were briefed by the researcher on the purpose of and procedure for the study and were asked to choose a peer or co-worker who would complete the VWB scale. To preserve confidentiality and anonymity, employees generated a coded number consisting of 7 digits. Employees then completed the selfreport survey instrument during the session and co-workers who completed the rating instruments, returned them within two days of the questionnaire distribution, in the sealed envelope, to a box placed in the Human Resources Department of the organizations. Of the 450 distributed instruments, 202 usable surveys (44.8\%) were returned.

\section{Results}

Descriptive statistics, correlations and Cronbach's alpha reliabilities for each study variable are presented in Table 1. The alpha coefficients for all measures used were all over the .70 minimum established by Nunnally (1978) ranging between .80 and .96 .

Work constraints, interpersonal conflict and role conflict were significantly positively correlated with CWBO, CWBI, negative emotion, and significantly negatively associated with courtesy and positive emotion. Role ambiguity was only significantly positively correlated with negative emotion and significantly negatively associated with positive emotion. Negative emotion was significantly positively associated with CWB, and significantly negatively correlated with OCB. Positive emotion was significantly positively correlated with all OCB factors.

\footnotetext{
${ }^{1}$ Goodness of fit statistics are available on request to the first author for all scales used in the study.
} 


\section{Insert Table 1 about here}

We employed the bootstrapping method with bias-corrected estimates based on 5000 resamples to test our mediation hypotheses (Preacher \& Hayes, 2008). Bootstrapping allowed us to test the indirect effects of each mediator simultaneously while controlling for other variables in the model and to compare the effects of the mediators with one another (Preacher \& Hayes, 2008). This enabled us to test whether positive and negative emotional reactions represent different processes and are differentially related to voluntary behaviours. Moreover, the bootstrapping approach does not rely on a normal sampling distribution and can be applied to small samples with more confidence (Preacher \& Hayes, 2004). Additionally, using the bootstrapping method reduces the likelihood of Type 1 error as the number of inferential tests is minimized. For bootstrap analyses, point estimates of indirect effects are considered significant when zero is not contained in the $95 \%$ confidence intervals.

Bootstrap analyses (Table 2) demonstrated evidence for negative emotion as a significant mediator between job stressors and CWB in all cases (controlling for positive emotion). Positive emotion was not found to be a significant mediator between job stressors and CWB (controlling for negative emotion). The contrast testing whether the two indirect effects differ significantly was not significant in all cases, indicating that two indirect effects cannot be distinguished in terms of magnitude. In addition, both positive and negative emotion were significant mediators between job stressors and citizenship behaviours in all cases except for the role-conflict-helping relationship. Once again, the contrast testing was not significant in all cases. 
Hierarchical moderated regression were computed to test hypotheses 3-8. We followed Aiken and West (1991) and Cohen et al., (2003) guidelines for testing the moderation hypothesis. In step 1, the control variables were entered. In step 2, the centred effects for independent variables were entered. In step 3, the centred effects for moderator variables were entered. In step 4, interaction terms computed using centred predictor and moderator variables were entered.

Results of moderated regression analyses are reported in table 3. We plotted significant interaction terms and reported regression slopes for low (-1 standard deviation) and high $(+1$ standard deviation) levels of the moderators ${ }^{2}$. Conscientiousness moderated the role ambiguitypositive emotion, work constraints-negative emotion, and role conflict-negative emotion relationships. High role ambiguity was associated with higher levels of positive emotion when conscientiousness was high and high work constraints and role conflict were associated with higher levels of negative emotion when conscientiousness was low (see Figure 1 and 2 for the work constraints data). Emotional stability moderated the role conflict-positive emotion relationship. High role conflict was associated with higher levels of positive emotion, when emotional stability was high. Extraversion moderated the work constraints-negative emotion relationship. High work constraints was associated with higher levels of negative emotion, when extraversion was low.

Agreeableness moderated the role ambiguity-positive emotion and role ambiguitynegative emotion relationships. High role ambiguity was associated with higher levels of positive

\footnotetext{
${ }^{2}$ Only two of the plotted significant interaction terms were included as an illustration. The other plotted significant interaction terms are available on request to the first author.
} 
emotion and lower levels of negative emotion, when agreeableness was high. EI was a moderator in the role ambiguity-negative emotion, interpersonal conflict-negative emotion, and role ambiguity-positive emotion relationships. High interpersonal conflict and role ambiguity was associated with lower levels of negative emotion and high role ambiguity was associated with higher levels of positive emotion, when EI was high. Thus, partial support was provided for the majority of the moderation hypotheses, with the exception of hypothesis 6 . Here, Openness failed to act as a moderator between job stressors and positive and negative emotion.

Insert Table 3 and Figure $2 \& 3$ about here

\section{Discussion}

This research tested the main propositions of Spector and Fox's (2002) model that an employee's positive or negative emotional reactions are induced by their perception/appraisal of the work environment and that induced emotion could lead to OCB or CWB. Positive emotion should produce OCB while negative emotions should produce CWB. Additionally, we tested the moderating effects of Big Five personality traits and ability-based EI, on the relationships between job stressors and positive and negative emotion. Table 4 provides a summary of supported and non-supported hypotheses.

\section{Insert Table 4 about here}

From a theoretical perspective, the findings of this study support the premise that work conditions as perceived by employees lead to emotional reactions, which influence CWB and 
OCB, thus concurring with the central role of emotion in Spector and Fox's (2002) model.

Firstly, a partial mediating role of negative emotion between job stressors and CWB emerged, which supports the notion that an employee's negative appraisal of the work environment induces negative emotion which in turn increases the likelihood of the employee engaging in CWB. Secondly, positive emotion did not emerge as a significant mediator between job stressors and CWB, suggesting that induced positive emotion resulting from an employee's positive appraisal of their work environment will not decrease the likelihood of the employee engaging in CWB. Thirdly, in eleven of the twelve analyses, both positive emotion and negative emotion were mediators of the relationship between job stressors and $\mathrm{OCB}$, lending weight to the idea that an employee's positive appraisal of the work environment induces positive emotion and increases the likelihood of the employee exhibiting OCB. Moreover, these findings suggest that negative appraisal of work environment induces negative emotion which in turn inhibits the likelihood of the employee performing OCB. Thus, mediation analyses provided some evidence that positive and negative emotional reactions represent different processes and are differentially related to $\mathrm{OCB}$ and $\mathrm{CWB}$.

Further, our findings suggest differential relationships between stressors and CWB and OCB. For instance, interpersonal conflict was more closely associated with CWBI than CWBO and role conflict and work constraints were more closely associated with CWBO than CWBI. Moreover, work constraints were more closely related with OCBO than interpersonal helping and interpersonal courtesy, and interpersonal conflict was more closely associated with interpersonal helping and interpersonal courtesy than OCBO. These differential relationships support the target-similarity model (Lavelle et al., 2007) in that perceptions about an entity predict social exchange with the entity which in turn predicts behaviour towards that entity. 
Although Lavelle et al., only focused on OCB in their model, Spector and Fox (2002) discuss target-specificity in relation to CWB.

Some evidence in the expected direction of the moderating role of Big Five personality traits, and EI in the relationships between job stressors and positive emotion and negative emotion emerged. For example, high conscientious, emotionally intelligent, and agreeable employees who perceived higher levels of role ambiguity, reported higher levels of positive emotion than those low in conscientiousness, EI and agreeableness. Extraverted and conscientious employees who perceived high work constraints reported lower levels of negative emotion than non-extraverted and conscientious employees. Therefore, evidence in support of moderation suggests that the Big Five personality traits and EI are likely to play an important role in the emotion regulation process. Conscientious, emotionally stable, extraverted, agreeable, and emotionally intelligent individuals are likely to make effective use of antecedent-focused emotion regulation strategies to attain desired affective states. Surprisingly, there was no support for the predicted moderating role of Openness.

\section{Limitations}

One advantage of this study is the use of other reports of OCB and CWB. In so doing, certain biases that might distort correlations of the OCB and CWB measures with participant reports of other variables are likely minimized. However, employees might have chosen coworkers who would report on their behaviours more favorably and furthermore, co-workers may only be cognizant of those behaviours that they can actually see (Fox, Spector, Goh, \& Bruursema, 2007).

Additionally, as the current study is of a cross-sectional nature, it cannot purport to provide a causal test of relationships. Therefore, future research should clarify the theorized 
relationships using longitudinal study designs. Further, testing individual linkages among variables specified in the model, rather than performing more robust analyses employing structural equation modelling is another limitation of this study. The sample size achieved in this study was smaller than the number of parameter estimates in model. In this regard, using a structural equation modelling methodology would have produced unreliable parameter estimates.

\section{Implications for $H R$}

From a practical standpoint, the findings from this study suggest that HRM policies and practices may have an important role to play in the effective management of emotions in the workplace, and thus in reducing negative workplace behaviours and increasing positive workplace behaviours. In particular, our results suggest that HRM practices such as recruitment and selection and training and development should be more emotion-oriented or focused. For example, including assessments of EI and theoretically-relevant personality traits in employee selection systems to select employees with effective emotional regulation tendencies can reduce negative emotion and $\mathrm{CWB}$ and enhance $\mathrm{OCB}$.

HR managers should also consider developing and implementing training and development programs geared towards helping employees engage in more effective emotion management and emotional regulation processes so that they can cope with the environmental demands of the workplace. In addition, to be effective in reducing negative emotion and enhancing positive emotion, the focus of HR managers should also be on creating more positive and supportive work environments through HRM policies and practices. Here, the key is not the policies and practices per se, but employees' perceptions of how managers implement and lead such policies and practices (Knies \& Leisink, 2014). Specifically, practices perceived to enhance employee well-being (commitment-focused) are more positively received than those perceived as 
control-focused (e.g. reduce costs and exploiting employees) (Nishii et al, 2008). Moreover, HR practices have causal effects different from their functional purpose. Those practices viewed by employees as 'personalised' commitment to them by the organisation as well as being effectively implemented and lead by managers may result in employees exhibiting positive attitudes and engaging in discretionary behaviours such as OCB and attendance (Purcell \& Hutchinson, 2007). Therefore, the manner in which HR practices are designed and implemented as well as perceived by employees will determine their influence on employees' attitudes and behaviours.

\section{References}

Aiken, L.S. and West, S.G. (1991). Multiple regression: Testing and interpreting interactions. Newbury Park, CA: Sage.

Baron, R.M. and Kenny, D.A. (1986). 'The moderator-mediator variable distinction in social psychological research: Conceptual, strategic, and statistical considerations.' Journal of Personality and Social Psychology, 51:6, 1173-1182.

Bennett, R.J. and Robinson, S.L. (2000). 'Development of a measure of workplace deviance.' Journal of Applied Psychology, 85:3, 349-360.

Bowling, N.A. and Eschleman, K.J. (2010). 'Employee personality as a moderator of the relationships between work stressors and counterproductive work behaviour.' Journal of Occupational Health Psychology, 15:1, 91-103.

Brunetto, Y., Teo, S.T.T., Shacklock, K. and Farr-Wharton, R. (2012). 'Emotional intelligence, job satisfaction, well-being and engagement: explaining organisational commitment and turnover intentions in policing' Human Resource Management Journal, 22:4, 428-441 
Caspi, A., Roberts, B.W. and Shiner, R. (2005). 'Personality development. Stability and change' Annual Review of Psychology, 56, 453-484.

Chao, J.M.C., Cheung, F.Y.L. and Wu, A.M.S (2011) 'Psychological contract breach and counterproductive workplace behaviors: testing moderating effect of attribution style and power distance' The International Journal of Human Resource Management, 22:4, 763777

Ciarrochi, J., Chan, A.Y. and Caputi, P. (2000). 'A critical evaluation of the emotional intelligence construct.' Personality \& Individual Differences, 28:3, 539-561.

Cohen, J., Cohen, P., West, S.G. and Aiken, L.S. (2003). Applied multiple regression/correlation analysis for the behavioural sciences (3rd ed,) Mahwah, NJ: Lawrence Erlbaum Associates.

Costa, P.T. Jr. and McCrae, R.R. (1992). Revised NEO Personality Inventory and Five-Factor Inventory professional manual. Odessa, FL: Psychological Assessment Resources.

Coyne, I., Gentile, D., Born, M., Cem, N. and Vakola, M. (2013). 'The Relationship between Productive and Counterproductive Work Behaviour across Four European Countries.' European Journal of Work and Organizational Psychology, 22:4, 377-389

Dalal, R.S. (2005). 'A meta-analysis of the relationship between organizational citizenship behaviour and counterproductive work behaviour.' Journal of Applied Psychology, 90:6, 1241-1255.

Davies, M., Stankov, L. and Roberts, R. (1998). 'Emotional intelligence: In search of an elusive construct.' Journal of Personality and Social Psychology, 75:4, 989-1015.

Fox, S. and Spector, P.E. (1999). 'A model of work frustration-aggression.' Journal of Organizational Behavior, 20:6, 915-931. 
Fox, S., Spector, P.E. and Miles, D. (2001). 'Counterproductive work behaviour (CWB) in response to job stressors and organizational justice: Some mediator and moderator tests for autonomy and emotions.' Journal of Vocational Behavior, 59:3, 291-309.

Fox, S., Spector, P.E., Goh, A. and Bruursema, K. (2007). 'Does your coworker know what you're doing? Convergence of self- and peer-reports of counterproductive work behavior' International Journal of Stress Management, 14:1, 41-60.

Frenkel, S., Restubog, S.L.B., and Bednall, T. (2012). 'How employee perceptions of HR policy and practice influence discretionary work effort and co-worker assistance: evidence from two organizations' The International Journal of Human Resource Management, 23:20, 4193-4210

Goldberg, L.R. (1999).' A broad-bandwidth, public-domain, personality inventory measuring the lower-level facets of several five-factor models.' In L. Mervielde, I. Deary, F. De Fruyt, \& F. Ostendorf (eds.), Personality psychology in Europe (Vol. 7, pp. 7-28). Tilburg, Netherlands: Tilburg University Press.

Gong, Y., Chang, S. and Cheung, S.Y. (2010). 'High performance work system and collective OCB: a collective social exchange perspective' Human Resource Management Journal, $20: 2,119-137$.

Gross, J.J (1998). 'The emerging field of emotion regulation: An integrative review.' Review of General Psychology, 2:3, 271-299.

Gross, J.J. and John, O.P. (1998). 'Mapping the domain of expressivity: Multimethod evidence for a hierarchical model.' Journal of Personality and Social Psychology, 74:1, 170-191. 
Gross, J.J. and John, O.P. (2003). 'Individual differences in two emotion regulation processes: Implications for affect, relationships, and well-being' Journal of Personality and Social Psychology, 85:2, 348-362.

Gunthert, K.C., Cohen, L.H. and Armeli, S. (1999). 'Role of neuroticism in daily stress and coping.' Journal of Personality and Social Psychology, 77:5, 1087-1100.

Hopkins, B. (2014). 'Explaining variations in absence rates: temporary and agency workers in the food manufacturing sector' Human Resource Management Journal, 24:2, 227-240

John, O.P. and Gross, J.J. (2004). 'Healthy and unhealthy emotion regulation: Personality processes, individual differences, and life span development.' Journal of Personality, $72: 6,1301-1333$.

John, OP. and Gross, J.J. (2007). 'Individual differences in emotion regulation strategies: Links to global trait, dynamic, and social cognitive constructs.' In J.J. Gross (ed.), Handbook of emotion regulation, New York: Guilford Press

Knies, E. and Leisink, P. (2014). 'Linking people management and extra-role behaviour: results of a longitudinal study’ Human Resource Management Journal, 24:1, 57-76

Lavelle, J.J., Rupp, D.E. and Brockner, J. (2007). 'Taking a Multifoci Approach to the Study of Justice, Social Exchange, and Citizenship Behavior: The Target Similarity Model? Journal of Management, 33:6, 841-866

Lazarus, R.S. (1993). 'From psychological stress to the emotions: A history of changing outlooks.' Annual Review of Psychology, 41, 1-24.

Law, K.S., Wong, C. and Song, L.J. (2004). 'The construct and criterion validity of emotional intelligence and its potential utility for management studies.' Journal of Applied Psychology, 89:3, 483-496. 
Mayer, J.D., Caruso, D. and Salovey, P. (1999). 'Emotional intelligence meets traditional standards for an intelligence.' Intelligence, 27:4, 267-298.

Mayer, J.D. and Salovey, P. (1997). 'What is emotional intelligence?' In P. Salovey \& D. Slutyer (eds.), Emotional development and emotional intelligence: Educational implications, New York: Basic Books.

Miles, D.E., Borman, W.E., Spector, P.E. and Fox, S. (2002). 'Building an integrative model of extra role work behaviours: A comparison of counterproductive work behaviour with organizational citizenship behaviour.' International Journal of Selection and Assessment, $10: 1-2,51-57$

Nishii, L., Lepak, D., and Schneider, B. (2008). 'Employee attributions of the why of HR practices: Their effects on employee attitudes and behaviours, and customer satisfaction.' Personnel Psychology, 61:3, 503-545.

Nunnally, J. (1978). Psychometric Theory, New York: McGraw-Hill.

Petrides, K. and Furnham, A. (2000). 'On the dimensional structure of emotional intelligence.' Personality and Individual Differences, 29:2, 313-320.

Preacher, K.J. and Hayes, A.F. (2004). 'SPSS and SAS procedures for estimating indirect effects in simple mediation models.' Behavior Research Methods, Instruments, \& Computers, $36: 4,717-731$.

Preacher, K.J. and Hayes, A.F. (2008). Asymptotic and resampling strategies for assessing and comparing indirect effects in multiple mediator models. Behavior Research Methods 40:3, 879-891 
Purcell, J. and Hutchinson, S. (2007). 'Front-line managers as agents in the HRM performance causal chain: theory, analysis and evidence’ Human Resource Management Journal, $17: 1,3-20$

Rizzo, J.R., House, R.J. and Lirtzman, S.I. (1970). 'Role conflict and ambiguity in complex organizations.' Administrative Science Quarterly, 15:2, 241-252.

Rotundo, M. and Sackett, P.R. (2002). 'The relative importance of task, citizenship, and counterproductive performance to global ratings of job performance: A policy-capturing approach.' Journal of Applied Psychology, 87:1, 66-80

Sackett, P.R., Berry, C.M., Wiemann, S.A. and Laczo, R.M. (2006). 'Citizenship and counterproductive work behaviour: Clarifying relations between two domains.' Human Performance, 19:4, 441-464.

Spector, P.E. (1998). 'A control theory of the job stress process.' In C.L. Cooper (ed.) Theories of organizational stress, Oxford: Oxford University Press.

Spector, P.E. and Fox, S. (2002). 'An emotion-centered model of voluntary work behaviour: Some parallels between counterproductive work behaviour (CWB) and organizational citizenship behaviour (OCB).' Human Resource Management Review. 12:2, 269-292

Spector, P.E. and Fox, S. (2010). 'Counterproductive Work Behavior and Organisational Citizenship Behavior: Are they opposite forms of active behaviour?' Applied Psychology: An International Review, 59:1, 21-39

Spector, P.E. and Jex, S.M. (1998). 'Development of four self-report measures of job stressors and strain: interpersonal conflict at work scale, organizational constraints scale, quantitative workload inventory, and physical symptoms inventory.' Journal of Occupational Health Psychology, 3:4, 356-367. 
Van Katwyk, P.T., Spector, P.E., Fox, S. and Kelloway, E.K. (2000). 'Using the Job-Related Affective Well-Being Scale (JAWS) to investigate affective responses to work stressors' Journal of Occupational Health Psychology, 5:2, 219-230.

Watson, D. and Clark, L.A. (1997). 'Extraversion and its positive emotional core.' In R. Hogan, J. A., Johnson, and S. R. Briggs (eds.), Handbook of personality psychology, San Diego, CA: Academic Press.

Wong, C. and Law, K.S. (2002). 'The effect of leader and follower emotional intelligence on performance and attitude: An exploratory study' The Leadership Quarterly, 23:3, 243274.

Woodrow, C. and Guest, D.E. (2014). 'When good HR gets bad results: exploring the challenge of HR implementation in the case of workplace bullying' Human Resource Management Journal, 24:1, 38-56 
Table 1.

Descriptive Statistics and Zero-ordered Correlations of Study Variables

\begin{tabular}{|c|c|c|c|c|c|c|c|c|c|c|c|}
\hline Variables & $\mathbf{M}$ & SD & 1 & 2 & 3 & 4 & 5 & 6 & 7 & 8 & 9 \\
\hline 1. Gender & & & & & & & & & & & \\
\hline 2. Age & 3.22 & 10.29 & -.00 & & & & & & & & \\
\hline 3. Tenure & 8.60 & 8.16 & -.07 & $.68^{* *}$ & & & & & & & \\
\hline 4. $\mathrm{CWBO}$ & 49.80 & 27.57 & .05 & -.05 & -.10 & $(.93)$ & & & & & \\
\hline 5. CWBI & 44.17 & 22.23 & .02 & -.06 & -.11 & $.72 * *$ & $(.89)$ & & & & \\
\hline 6. OCBO & 65.58 & 21.28 & -.02 & $.20^{* *}$ & $.17^{*}$ & $-.47 * *$ & $-.34 * *$ & $(.94)$ & & & \\
\hline 7. Helping & 66.72 & 15.67 & .05 & $.16^{*}$ & $.17^{*}$ & $-.25 * *$ & $-.40 * *$ & $.74 * *$ & $(.92)$ & & \\
\hline 8. Courtesy & 51.64 & 13.26 & -.00 & $.19^{* *}$ & $.15^{*}$ & $-.34 * *$ & $-.53 * *$ & $.72 * *$ & $.87 * *$ & $(.91)$ & \\
\hline 9. Positive Emotions & 3.17 & 1.06 & $-.25^{* *}$ & $.21^{* *}$ & $.18^{* *}$ & -.12 & -.09 & $.28 * *$ & $.21 * *$ & $.28 * *$ & $(.96)$ \\
\hline 10. Negative Emotions & 2.49 & .86 & $.17^{*}$ & -.08 & $-.15^{*}$ & $.34 * *$ & $.30 * *$ & $-.33 * *$ & $-.27 * *$ & $-.29 * *$ & $-.52 * *$ \\
\hline 11. Interpersonal Conflict & 1.95 & .77 & .04 & -.07 & -.10 & $.31 * *$ & $.36 * *$ & -.12 & $-.20 * *$ & $-.21 * *$ & $-.14 *$ \\
\hline 12. Work Constraints & 2.04 & .75 & .01 & $-.17^{*}$ & $-.15^{*}$ & $.34 * *$ & $.30 * *$ & $-.30 * *$ & $-.24 * *$ & $-.28 * *$ & $-.26^{* *}$ \\
\hline 13. Role Ambiguity & 2.62 & 1.63 & .07 & $-.14^{*}$ & $-.16^{*}$ & .04 & .00 & -.13 & -.12 & -.10 & $-.38 * *$ \\
\hline 14. Role Conflict & 3.76 & 1.64 & .03 & $-.16^{*}$ & $-.15^{*}$ & $.30 * *$ & $.26 * *$ & -.11 & -.13 & $-.15^{*}$ & $-.15^{*}$ \\
\hline 15. Extraversion & 3.11 & .83 & -.05 & -.08 & -.07 & $.24 * *$ & .10 & -.07 & .02 & -.01 & .03 \\
\hline 16. Agreeableness & 3.59 & 1.00 & -.05 & $.21^{* *}$ & $.24^{* *}$ & $-.24 * *$ & $-.29 * *$ & $.26 * *$ & $.22 * *$ & $.29 * *$ & $.35 * *$ \\
\hline 17. Conscientiousness & 3.66 & 1.00 & -.07 & .09 & .11 & $-.25 * *$ & $-.24 * *$ & $.27 * *$ & $.17 *$ & $.23 * *$ & $.43^{* *}$ \\
\hline 18. Emotional Stability & 3.22 & 1.07 & $-.17^{*}$ & $.17^{*}$ & $.16^{*}$ & $-.24 * *$ & $-.24 * *$ & $.36^{* *}$ & $.28 * *$ & $.31^{* *}$ & $.39 * *$ \\
\hline 19. Openness & 3.54 & .62 & .07 & -.07 & -.00 & .037 & -.03 & .04 & .04 & .04 & .10 \\
\hline 20. Ability EI & 5.40 & 1.32 & .00 & .04 & .12 & $-.38 * *$ & $-.28 * *$ & $.42 * *$ & $.27 * *$ & $.32 * *$ & $.18^{*}$ \\
\hline
\end{tabular}


Table 1 (continued)

\begin{tabular}{|c|c|c|c|c|c|c|c|c|c|c|c|}
\hline Variables & 10 & 11 & 12 & 13 & 14 & 15 & 16 & 17 & 18 & 19 & 20 \\
\hline 10. Negative Emotions & $(.93)$ & & & & & & & & & & \\
\hline 11. Interpersonal Conflict & $.30 * *$ & $(.81)$ & & & & & & & & & \\
\hline 12. Work Constraints & $.51 * *$ & $.52 * *$ & $(.87)$ & & & & & & & & \\
\hline 13. Role Ambiguity & $.35^{* *}$ & .11 & $.25 * *$ & $(.92)$ & & & & & & & \\
\hline 14. Role Conflict & $.37 * *$ & $.32 *$ & $.47 * *$ & .09 & $(.90)$ & & & & & & \\
\hline 15. Extraversion & .08 & .00 & -.00 & -.09 & $.157 *$ & $(.88)$ & & & & & \\
\hline 16. Agreeableness & $-.31 * *$ & $-.14^{*}$ & $-.16^{*}$ & $-.23 * *$ & -.00 & .01 & $(.92)$ & & & & \\
\hline 17. Conscientiousness & $-.36 * *$ & -.12 & $-.13 *$ & $-.22 * *$ & -.03 & -.06 & $.50 * *$ & $(.93)$ & & & \\
\hline 18. Emotional Stability & $-.46 * *$ & -.08 & -.10 & $-.27 * *$ & -.08 & -.00 & $.39 * *$ & $.41 * *$ & $(.93)$ & & \\
\hline 19. Openness & .01 & -.01 & .03 & -.13 & .01 & $.24 * *$ & .13 & $.20 * *$ & .03 & $(.80)$ & \\
\hline 20. Ability EI & $-.31 * *$ & -.07 & $-.15 *$ & $-.22 * *$ & $-.16^{*}$ & .08 & .30 & $.27 * *$ & $.31 * *$ & $.28 * *$ & $(.97)$ \\
\hline
\end{tabular}




\section{Table 2}

\section{Testing the Mediating Role of Negative Emotion and Positive Emotion}

\begin{tabular}{|c|c|c|c|c|c|c|c|c|c|}
\hline \multirow[b]{2}{*}{$\begin{array}{c}\text { Independent Variable } \\
\text { (IV) }\end{array}$} & \multirow[b]{2}{*}{ M } & \multirow[b]{2}{*}{ DV } & \multirow{2}{*}{$\begin{array}{l}\text { Effect } \\
\text { of IV } \\
\text { on M } \\
\text { (a) }\end{array}$} & \multirow{2}{*}{$\begin{array}{c}\text { Effect } \\
\text { of M on } \\
\text { DV (b) }\end{array}$} & \multirow{2}{*}{$\begin{array}{c}\text { Direct } \\
\text { Effect of } \\
\text { IV on DV } \\
\left(c^{\prime}\right)\end{array}$} & \multirow{2}{*}{$\begin{array}{c}\text { Indirect } \\
\text { Effect } \\
(a b)\end{array}$} & \multicolumn{2}{|c|}{$\mathrm{BCa} * 95 \% \mathrm{CI}$} & \multirow[b]{2}{*}{$\begin{array}{r}\text { Total } \\
\text { Effects }\end{array}$} \\
\hline & & & & & & & Lower & Upper & \\
\hline \multirow[t]{3}{*}{ Interpersonal Conflict } & $\mathrm{PE}$ & CWBO & -.20 & 1.91 & 8.33 & -.38 & -1.79 & .19 & 11.36 \\
\hline & $\mathrm{NE}$ & & .35 & 9.88 & & $3.41^{\mathrm{a}}$ & 1.48 & 6.17 & \\
\hline & PE vs. NE & & & & & -3.79 & -7.26 & -1.56 & \\
\hline \multirow[t]{3}{*}{ Work Constraints } & $\mathrm{PE}$ & CWBO & -.38 & 2.05 & 8.42 & -.77 & -2.78 & .59 & 12.61 \\
\hline & $\mathrm{NE}$ & & .58 & 8.50 & & $4.96^{\mathrm{a}}$ & 1.51 & 9.23 & \\
\hline & PE vs. NE & & & & & -5.74 & -10.83 & -1.64 & \\
\hline \multirow[t]{3}{*}{ Role Conflict } & $\mathrm{PE}$ & CWBO & -.10 & 1.76 & 3.41 & -.18 & -.73 & .18 & 5.12 \\
\hline & $\mathrm{NE}$ & & .19 & 9.65 & & $1.89^{\mathrm{a}}$ & .91 & 3.23 & \\
\hline & PE vs. NE & & & & & -2.06 & -3.69 & -.89 & \\
\hline \multirow[t]{3}{*}{ Role Ambiguity } & $\mathrm{PE}$ & CWBO & -.25 & 1.57 & 1.16 & -.39 & -1.56 & .77 & 3.12 \\
\hline & $\mathrm{NE}$ & & .18 & 12.73 & & $2.35^{\mathrm{a}}$ & 1.05 & 3.85 & \\
\hline & PE vs. NE & & & & & -2.75 & -4.64 & -.98 & \\
\hline \multirow[t]{3}{*}{ Interpersonal Conflict } & $\mathrm{PE}$ & CWBI & -.19 & 1.56 & 8.60 & -.31 & -1.67 & .19 & 10.50 \\
\hline & $\mathrm{NE}$ & & .34 & 6.41 & & $2.21^{\mathrm{a}}$ & .75 & 4.61 & \\
\hline & PE vs. NE & & & & & -2.52 & -5.69 & -.74 & \\
\hline
\end{tabular}

Note. ${ }^{a}$ Significant point estimate $(\mathrm{p}<.05)$. * $\mathrm{BCa}=$ bias corrected and accelerated bootstrapping confidence intervals that include corrections for both median bias and skew. Confidence intervals containing a zero are interpreted as not significant; 5000 bootstrap samples. PE = Positive Emotion; NE = Negative Emotion 
Table 2 (continued)

\begin{tabular}{|c|c|c|c|c|c|c|c|c|c|}
\hline \multirow[b]{2}{*}{$\begin{array}{c}\text { Independent Variable } \\
\text { (IV) }\end{array}$} & \multirow[b]{2}{*}{$\mathrm{M}$} & \multirow[b]{2}{*}{ DV } & \multirow{2}{*}{$\begin{array}{l}\text { Effect } \\
\text { of IV } \\
\text { on M } \\
\text { (a) }\end{array}$} & \multirow{2}{*}{$\begin{array}{l}\text { Effect } \\
\text { of M on } \\
\text { DV (b) }\end{array}$} & \multirow{2}{*}{$\begin{array}{c}\text { Direct } \\
\text { Effect of } \\
\text { IV on DV } \\
\left(c^{\prime}\right)\end{array}$} & \multirow{2}{*}{$\begin{array}{c}\text { Indirect } \\
\text { Effect } \\
(a b)\end{array}$} & \multicolumn{2}{|c|}{ BCa* 95\% CI } & \multirow[b]{2}{*}{$\begin{array}{l}\text { Total } \\
\text { Effects }\end{array}$} \\
\hline & & & & & & & Lower & Upper & \\
\hline \multirow[t]{3}{*}{ Work Constraints } & $\mathrm{PE}$ & CWBI & -.37 & 1.70 & 6.10 & -.64 & -2.30 & .45 & 9.06 \\
\hline & $\mathrm{NE}$ & & .58 & 6.16 & & $3.60^{\mathrm{a}}$ & 1.21 & 6.91 & \\
\hline & PE vs. NE & & & & & -4.24 & -8.50 & -1.13 & \\
\hline \multirow[t]{3}{*}{ Role Conflict } & $\mathrm{PE}$ & CWBI & -.10 & 1.50 & 2.40 & -.15 & -.69 & .13 & 3.62 \\
\hline & $\mathrm{NE}$ & & .19 & 7.04 & & $1.37^{\mathrm{a}}$ & .52 & 2.53 & \\
\hline & PE vs. NE & & & & & -1.52 & -2.93 & -.49 & \\
\hline \multirow[t]{3}{*}{ Role Ambiguity } & $\mathrm{PE}$ & CWBI & -.25 & 1.09 & 1.50 & -.28 & -1.29 & .60 & 2.97 \\
\hline & $\mathrm{NE}$ & & .18 & 9.47 & & $1.75^{\mathrm{a}}$ & .73 & 3.10 & \\
\hline & PE vs. NE & & & & & -2.03 & -3.88 & -.62 & \\
\hline \multirow[t]{3}{*}{ Interpersonal Conflict } & $\mathrm{PE}$ & OCBO & -.19 & 3.09 & -.90 & .61 & .02 & 2.06 & 1.74 \\
\hline & $\mathrm{NE}$ & & .34 & -5.89 & & 2.03 & .69 & 3.84 & \\
\hline & PE vs. NE & & & & & -1.42 & -3.43 & -.32 & \\
\hline \multirow[t]{3}{*}{ Work Constraints } & $\mathrm{PE}$ & OCBO & -.37 & 3.08 & -1.85 & $1.15^{\mathrm{a}}$ & .02 & 2.85 & 2.14 \\
\hline & $\mathrm{NE}$ & & .58 & -4.87 & & $2.84^{\mathrm{a}}$ & .29 & 5.60 & \\
\hline & PE vs. NE & & & & & -1.69 & -2.94 & 1.51 & \\
\hline
\end{tabular}

Note. ${ }^{\mathrm{a}}$ Significant point estimate $(\mathrm{p}<.05) .{ }^{*} \mathrm{BCa}=$ bias corrected and accelerated bootstrapping confidence intervals that include corrections for both median bias and skew. Confidence intervals containing a zero are interpreted as not significant; 5000 bootstrap samples. PE $=$ Positive Emotion; NE $=$ Negative Emotion 
Table 2 (continued)

\begin{tabular}{|c|c|c|c|c|c|c|c|c|c|}
\hline \multirow{2}{*}{$\begin{array}{l}\text { Independent Variable } \\
\text { (IV) }\end{array}$} & \multirow[b]{2}{*}{ M } & \multirow[b]{2}{*}{ DV } & \multirow{2}{*}{$\begin{array}{l}\text { Effect } \\
\text { of IV } \\
\text { on M } \\
\text { (a) }\end{array}$} & \multirow{2}{*}{$\begin{array}{c}\text { Effect } \\
\text { of M on } \\
\text { DV (b) }\end{array}$} & \multirow{2}{*}{$\begin{array}{c}\text { Direct } \\
\text { Effect of } \\
\text { IV on DV } \\
\left(c^{\prime}\right)\end{array}$} & \multirow{2}{*}{$\begin{array}{c}\text { Indirect } \\
\text { Effect } \\
(a b)\end{array}$} & \multicolumn{2}{|c|}{$\mathrm{BCa} * 95 \% \mathrm{CI}$} & \multirow{2}{*}{$\begin{array}{l}\text { Total } \\
\text { Effects }\end{array}$} \\
\hline & & & & & & & Lower & Upper & \\
\hline \multirow[t]{3}{*}{ Role Conflict } & $\mathrm{PE}$ & OCBO & -.10 & 3.07 & -.02 & $.30^{\mathrm{a}}$ & .002 & 1.08 & 1.49 \\
\hline & & & .19 & -6.17 & & $1.21^{\mathrm{a}}$ & .46 & 2.32 & \\
\hline & PE vs. NE & & & & & -.91 & -1.52 & 2.12 & \\
\hline \multirow[t]{3}{*}{ Role Ambiguity } & $\mathrm{PE}$ & OCBO & -.25 & 3.15 & -.18 & $.80^{\mathrm{a}}$ & .06 & 1.85 & 1.82 \\
\hline & $\mathrm{NE}$ & & .18 & -6.22 & & $1.20^{\mathrm{a}}$ & .37 & 2.29 & \\
\hline & PE vs. NE & & & & & -.40 & -1.88 & 1.00 & \\
\hline \multirow[t]{3}{*}{ Interpersonal Conflict } & $\mathrm{PE}$ & Courtesy & -.19 & 1.99 & -.37 & $.59^{\mathrm{a}}$ & .03 & 1.43 & 1.59 \\
\hline & $\mathrm{NE}$ & & .34 & -3.18 & & $1.10^{\mathrm{a}}$ & .11 & 2.54 & \\
\hline & PE vs. NE & & & & & -.51 & -1.67 & 2.31 & \\
\hline \multirow[t]{3}{*}{ Work Constraints } & $\mathrm{PE}$ & Courtesy & -.37 & 2.01 & -.90 & $.73^{\mathrm{a}}$ & .17 & 1.97 & 1.15 \\
\hline & $\mathrm{NE}$ & & .58 & -2.27 & & $1.32^{\mathrm{a}}$ & .47 & 3.32 & \\
\hline & PE vs. NE & & & & & -.59 & -1.84 & 3.12 & \\
\hline \multirow[t]{3}{*}{ Role Conflict } & $\mathrm{PE}$ & Courtesy & -.10 & 2.01 & -.52 & .21 & .01 & .68 & .59 \\
\hline & $\mathrm{NE}$ & & .19 & -3.62 & & .90 & .14 & 1.50 & \\
\hline & PE vs. NE & & & & & -.69 & -1.31 & 1.42 & \\
\hline
\end{tabular}

Note. ${ }^{a}$ Significant point estimate $(\mathrm{p}<.05) .{ }^{*} \mathrm{BCa}=$ bias corrected and accelerated bootstrapping confidence intervals that include corrections for both median bias and skew. Confidence intervals containing a zero are interpreted as not significant; 5000 bootstrap samples. $\mathrm{PE}=$ Positive Emotion; NE = Negative Emotion 
Table 2 (continued)

\begin{tabular}{|c|c|c|c|c|c|c|c|c|c|}
\hline \multirow{2}{*}{$\begin{array}{l}\text { Independent Variable } \\
\text { (IV) }\end{array}$} & \multirow[b]{2}{*}{$\mathrm{M}$} & \multirow[b]{2}{*}{ DV } & \multirow{2}{*}{$\begin{array}{l}\text { Effect } \\
\text { of IV } \\
\text { on M } \\
\text { (a) }\end{array}$} & \multirow{2}{*}{$\begin{array}{l}\text { Effect } \\
\text { of M on } \\
\text { DV (b) }\end{array}$} & \multirow{2}{*}{$\begin{array}{c}\text { Direct } \\
\text { Effect of } \\
\text { IV on DV } \\
\left(c^{\prime}\right)\end{array}$} & \multirow{2}{*}{$\begin{array}{c}\text { Indirect } \\
\text { Effect } \\
(a b)\end{array}$} & \multicolumn{2}{|c|}{$\mathrm{BCa} * 95 \% \mathrm{CI}$} & \multirow{2}{*}{$\begin{array}{c}\text { Total } \\
\text { Effects }\end{array}$} \\
\hline & & & & & & & Lower & Upper & \\
\hline \multirow[t]{3}{*}{ Role Ambiguity } & $\mathrm{PE}$ & Courtesy & -.25 & 2.02 & -.22 & $.50^{\mathrm{a}}$ & .09 & 1.28 & 1.04 \\
\hline & & & .18 & -4.11 & & $.76^{\mathrm{a}}$ & .17 & 1.63 & \\
\hline & PE vs. NE & & & & & -.26 & -.84 & 1.47 & \\
\hline \multirow[t]{3}{*}{ Interpersonal Conflict } & $\mathrm{PE}$ & Helping & -.19 & 1.50 & -1.29 & 1.24 & .89 & 2.16 & 1.92 \\
\hline & $\mathrm{NE}$ & & .34 & -2.83 & & 1.97 & 1.21 & 2.68 & \\
\hline & PE vs. NE & & & & & -.73 & -.43 & 2.00 & \\
\hline \multirow[t]{3}{*}{ Work Constraints } & $\mathrm{PE}$ & Helping & -.37 & 1.17 & -.38 & $.44^{\mathrm{a}}$ & .28 & 1.49 & 1.06 \\
\hline & $\mathrm{NE}$ & & .58 & -1.72 & & $1.00^{\mathrm{a}}$ & .44 & 2.60 & \\
\hline & PE vs. NE & & & & & -.56 & -1.43 & 2.56 & \\
\hline \multirow[t]{3}{*}{ Role Conflict } & $\mathrm{PE}$ & Helping & -.10 & 1.19 & -.32 & -.11 & -.49 & .05 & .42 \\
\hline & $\mathrm{NE}$ & & .19 & -3.25 & & -.63 & -1.27 & -.18 & \\
\hline & PE vs. NE & & & & & .51 & -.11 & 1.21 & \\
\hline \multirow[t]{3}{*}{ Role Ambiguity } & $\mathrm{PE}$ & Helping & -.25 & 1.11 & -.12 & $.28^{\mathrm{a}}$ & .04 & .94 & .90 \\
\hline & $\mathrm{NE}$ & & .18 & -3.45 & & $.63^{\mathrm{a}}$ & .14 & 1.32 & \\
\hline & PE vs. NE & & & & & -.36 & -.58 & 1.34 & \\
\hline
\end{tabular}

Note. ${ }^{a}$ Significant point estimate $(\mathrm{p}<.05) .{ }^{*} \mathrm{BCa}=$ bias corrected and accelerated bootstrapping confidence intervals that include corrections for both median bias and skew. Confidence intervals containing a zero are interpreted as not significant; 5000 bootstrap samples. $\mathrm{PE}=$ Positive Emotion; NE $=$ Negative Emotion 
Table 3

Hierarchical Moderated Regression Analyses Testing the Moderating Effect of Big Five Personality Factors and Ability Based EI

\begin{tabular}{|c|c|c|c|c|c|c|c|c|c|}
\hline \multirow[b]{2}{*}{ Predictor Variables } & \multicolumn{4}{|c|}{ Negative Emotion } & \multirow[b]{2}{*}{ Predictor Variables } & \multicolumn{4}{|c|}{ Positive Emotion } \\
\hline & Step 1 & Step 2 & Step 3 & Step 4 & & Step 1 & Step 2 & Step 3 & Step 4 \\
\hline Gender & $.17^{*}$ & $.15^{*}$ & $.13 *$ & $13 *$ & Gender & $-.25 * *$ & $-.23 * *$ & $-.21 * *$ & $-.20 * *$ \\
\hline Age & .02 & .08 & .08 & .08 & Age & $.18^{*}$ & $.16^{*}$ & $.15^{*}$ & .15 \\
\hline Tenure & -.15 & -.11 & -.09 & -.09 & Tenure & .03 & -.00 & -.02 & -.03 \\
\hline WC & & $.50 * *$ & $.47 * *$ & $.48 * *$ & RA & & $-.34 * *$ & $-.27 * *$ & $-.29 * *$ \\
\hline CONCIEN & & & $-.29 * *$ & $-.30 * *$ & CONCIEN & & & $.34 * *$ & $.35 * *$ \\
\hline WC x CONCIEN & & & & $-.12 *$ & RA x CONCIEN & & & & $-.13 *$ \\
\hline $\mathrm{R}^{2}$ & .05 & .30 & .38 & .40 & $\mathrm{R}^{2}$ & .11 & .23 & .34 & .36 \\
\hline $\mathrm{R}^{2} \Delta$ & & $.25 * *$ & $.08 * *$ & $.02 *$ & $\mathrm{R}^{2} \Delta$ & & $.12 * *$ & $.11^{* *}$ & $.02 *$ \\
\hline \multirow[t]{2}{*}{$\mathrm{F}$} & $3.72 *$ & $20.88 * *$ & $24.03 * *$ & $21.21 * *$ & $\mathrm{~F}$ & $8.34 * *$ & $14.57 * *$ & $20.33 * *$ & $18.29 * *$ \\
\hline & \multicolumn{4}{|c|}{ Negative Emotion } & & \multicolumn{4}{|c|}{ Positive Emotion } \\
\hline Predictor Variables & Step 1 & Step 2 & Step 3 & Step 4 & Predictor Variables & Step 1 & Step 2 & Step 3 & Step 4 \\
\hline Gender & $.17^{*}$ & $.15^{*}$ & $.13 *$ & $.14^{*}$ & Gender & $-.25 * *$ & $-.23 * *$ & $-.23 * *$ & $-.20 * *$ \\
\hline Age & .02 & .05 & .06 & .07 & Age & $.18^{*}$ & $.16^{*}$ & $.17^{*}$ & .15 \\
\hline Tenure & -.15 & -.12 & -.09 & -.11 & Tenure & .03 & -.00 & -.02 & -.02 \\
\hline $\mathrm{RC}$ & & $.36 * *$ & $.36 * *$ & $.37 * *$ & RA & & $-.34 * *$ & $-.32 * *$ & $-.37 * *$ \\
\hline CONCIEN & & & $-.34 * *$ & $.35 * *$ & AEI & & & .10 & $.15^{*}$ \\
\hline RC x CONCIEN & & & & $-.17 * *$ & RA x AEI & & & & $-.25 * *$ \\
\hline $\mathrm{R}^{2}$ & .05 & .18 & .29 & .32 & $\mathrm{R}^{2}$ & .11 & .23 & .24 & .29 \\
\hline $\mathrm{R}^{2} \Delta$ & & $.13 * *$ & $.11^{* *}$ & $.03 * *$ & $\mathrm{R}^{2} \Delta$ & & $.12 * *$ & .01 & $.05^{* *}$ \\
\hline $\mathrm{F}$ & $3.72 *$ & $10.73 * *$ & $16.27 * *$ & $15.64 * *$ & $\mathrm{~F}$ & $8.34 * *$ & $14.57 * *$ & $12.28 * *$ & $13.67 * *$ \\
\hline
\end{tabular}


Table 3 (continued)

\begin{tabular}{|c|c|c|c|c|c|c|c|c|c|}
\hline \multirow[b]{2}{*}{ Predictor Variables } & \multicolumn{4}{|c|}{ Negative Emotion } & \multirow[b]{2}{*}{ Predictor Variables } & \multicolumn{4}{|c|}{ Negative Emotion } \\
\hline & Step 1 & Step 2 & Step 3 & Step 4 & & Step 1 & Step 2 & Step 3 & Step 4 \\
\hline Gender & $.17 *$ & $.14^{*}$ & $.15^{*}$ & .12 & Gender & $.17^{*}$ & $.15^{*}$ & $.16^{*}$ & $.15^{*}$ \\
\hline Age & .02 & .03 & .01 & .02 & Age & .02 & .02 & -.00 & .00 \\
\hline Tenure & -.15 & -.11 & -.07 & -.07 & Tenure & -.15 & -.12 & -.07 & -.09 \\
\hline RA & & $.32 * *$ & $.27 * *$ & $.31 * *$ & $\mathrm{IC}$ & & $.29 * *$ & $.27 * *$ & $.28 * *$ \\
\hline AEI & & & $-.24 * *$ & $-.28 * *$ & AEI & & & $-.28 * *$ & $-.27 * *$ \\
\hline RA $x$ AEI & & & & $.24 * *$ & IC x AEI & & & & $-.12 *$ \\
\hline $\mathrm{R}^{2}$ & .05 & .15 & .21 & .26 & $\mathrm{R}^{2}$ & .05 & .13 & .21 & .23 \\
\hline $\mathrm{R}^{2} \Delta$ & & $.10 * *$ & $.06^{* *}$ & $.05 * *$ & $\mathrm{R}^{2} \Delta$ & & $.08 * *$ & $.08 * *$ & $.02 *$ \\
\hline \multirow[t]{2}{*}{$\mathrm{F}$} & $3.72 *$ & $9.02 * *$ & $10.34 * *$ & $11.58 * *$ & $\mathrm{~F}$ & $3.72 *$ & $7.76^{* *}$ & $10.66^{* *}$ & $9.70 * *$ \\
\hline & \multicolumn{4}{|c|}{ Negative Emotion } & & \multicolumn{4}{|c|}{ Positive Emotion } \\
\hline Predictor Variables & Step 1 & Step 2 & Step 3 & Step 4 & Predictor Variables & Step 1 & Step 2 & Step 3 & Step 4 \\
\hline Gender & $.17^{*}$ & $.14^{*}$ & $.14^{*}$ & $.14^{*}$ & Gender & $-.25 * *$ & $-.23 * *$ & $-.22 * *$ & $-.22 * *$ \\
\hline Age & .02 & .03 & .05 & .06 & Age & $.18^{*}$ & $.16^{*}$ & .14 & .14 \\
\hline Tenure & -.15 & -.11 & -.08 & -.06 & Tenure & .03 & -.00 & -.04 & -.06 \\
\hline RA & & $.32 * *$ & $.28 * *$ & $.29 * *$ & RA & & $-.34 * *$ & $-.30 * *$ & $-.32 * *$ \\
\hline AGREE & & & $-.23 * *$ & $-.25 * *$ & AGREE & & & $-.25 * *$ & $.28 * *$ \\
\hline RA $x$ AGREE & & & & $.14^{*}$ & RA $x$ AGREE & & & & $-.19 * *$ \\
\hline $\mathrm{R}^{2}$ & .05 & .15 & .20 & .23 & $\mathrm{R}^{2}$ & .11 & .23 & .28 & .32 \\
\hline $\mathrm{R}^{2} \Delta$ & & $.10 * *$ & $.05 * *$ & $.03 *$ & $\mathrm{R}^{2} \Delta$ & & $.12 * *$ & $.05 * *$ & $.04 * *$ \\
\hline $\mathrm{F}$ & $3.72 *$ & $9.02 * *$ & $10.10 * *$ & $9.42 * *$ & $\mathrm{~F}$ & $8.34 * *$ & $14.57 * *$ & $15.79 * *$ & $15.56^{* *}$ \\
\hline
\end{tabular}


Table 3 (continued)

\begin{tabular}{|c|c|c|c|c|c|c|c|c|c|}
\hline \multirow[b]{2}{*}{ Predictor Variables } & \multicolumn{4}{|c|}{ Negative Emotion } & & \multicolumn{4}{|c|}{ Positive Emotion } \\
\hline & Step 1 & Step 2 & Step 3 & Step 4 & & Step 1 & Step 2 & Step 3 & Step 4 \\
\hline Gender & $.17^{*}$ & $.15^{*}$ & $.16^{*}$ & $.16^{*}$ & Gender & $-.25 * *$ & $-.25 * *$ & $-.19 * *$ & $-.20 * *$ \\
\hline Age & .02 & .08 & .08 & .09 & Age & $.18^{*}$ & .17 & .13 & .12 \\
\hline Tenure & -.15 & -.11 & -.11 & -.10 & Tenure & .03 & .02 & -.00 & .00 \\
\hline $\mathrm{WC}$ & & $.50 * *$ & $.50 * *$ & $.51 * *$ & $\mathrm{RC}$ & & -.12 & -.10 & -.10 \\
\hline EXT & & & -.10 & -.11 & $\mathrm{ES}$ & & & $.34 * *$ & $.32 * *$ \\
\hline WC $x$ EXT & & & & $-.15^{*}$ & $\mathrm{RC} \times \mathrm{ES}$ & & & & $.14^{*}$ \\
\hline $\mathrm{R}^{2}$ & .05 & .30 & 31 & 33 & $\mathrm{R}^{2}$ & .11 & .12 & .23 & .25 \\
\hline $\mathrm{R}^{2} \Delta$ & & $.25 * *$ & .01 & $.02 *$ & $\mathrm{R}^{2} \Delta$ & & .01 & $.11 * *$ & $.02 * *$ \\
\hline $\mathrm{F}$ & $3.72 *$ & $20.88^{* *}$ & $17.31 * *$ & $18.96 * *$ & $\mathrm{~F}$ & $8.34 * *$ & $7.12 * *$ & $11.92 * *$ & $11.08 * *$ \\
\hline
\end{tabular}


Table 4.

Summary of Supported and Non Supported Hypotheses

\begin{tabular}{llc}
\hline & \multicolumn{1}{c}{ Hypotheses } & Support for Hypothesis \\
\hline Hypothesis 1 & $\begin{array}{l}\text { Negative emotion as mediator } \\
\text { between stressors and CWB } \\
\text { Positive emotion as mediator between } \\
\text { stressors and OCB } \\
\text { Conscientious as moderator between } \\
\text { stressors and emotion }\end{array}$ & Yes \\
Hypothesis 3 & $\begin{array}{l}\text { Emotional Stability as moderator } \\
\text { between stressors and emotion } \\
\text { Eypothesis } 4\end{array}$ & Some support \\
Hypothesis 5 & $\begin{array}{l}\text { Extraversion as moderator between } \\
\text { Stressond and emotion }\end{array}$ & Some support \\
Hypothesis 6 & $\begin{array}{l}\text { Stressors and emotion } \\
\text { EI as moderator between stressors } \\
\text { and emotion }\end{array}$ & Some support \\
\hline Hypothesis 7
\end{tabular}


Figure 1: Proposed Relationships among Study Variables

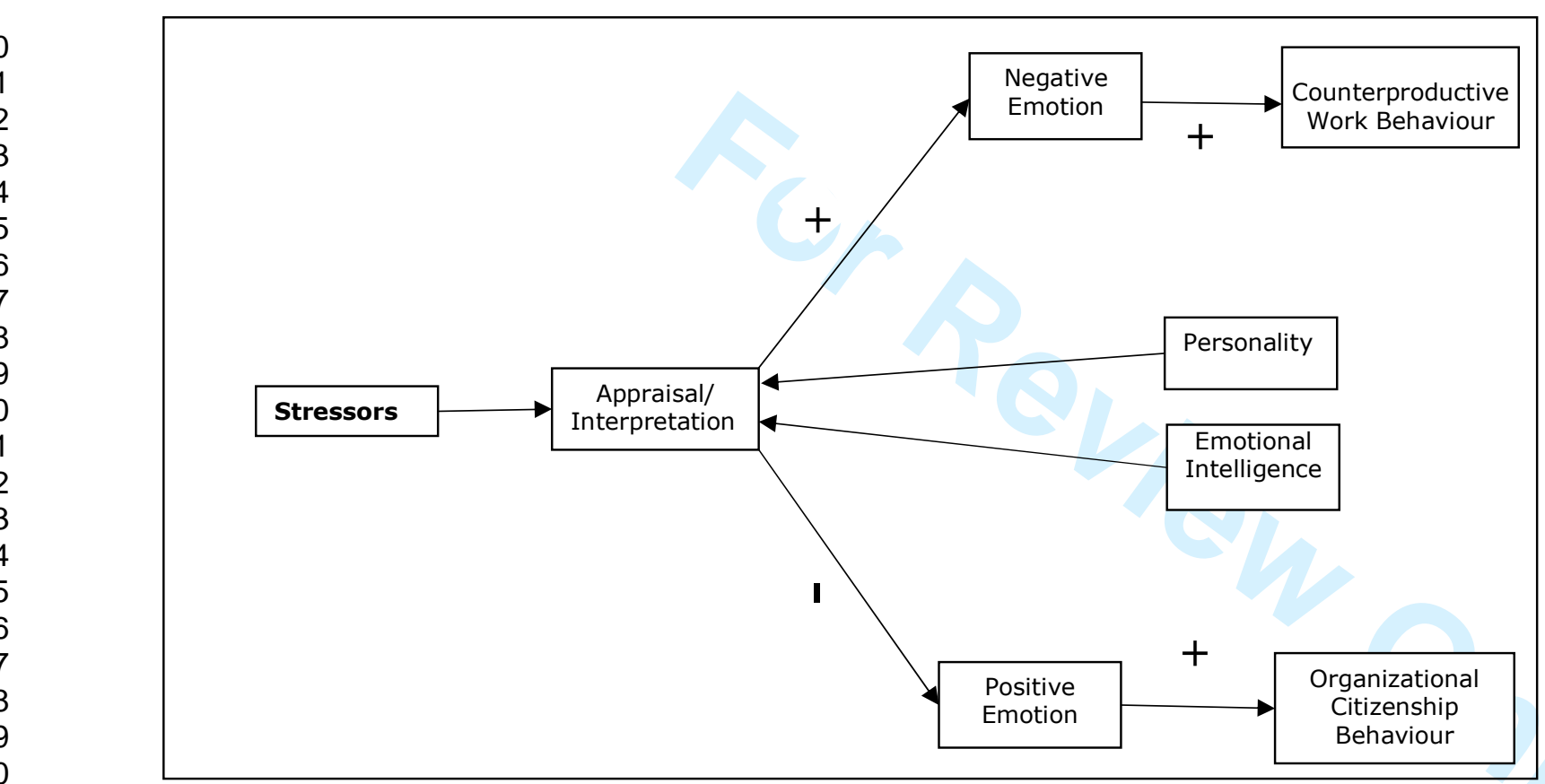

32

34

35

36

38

39

40

41

42

43

44

45

46

47

48

\section{igure 1: Proposed Relationships among Study Variables}




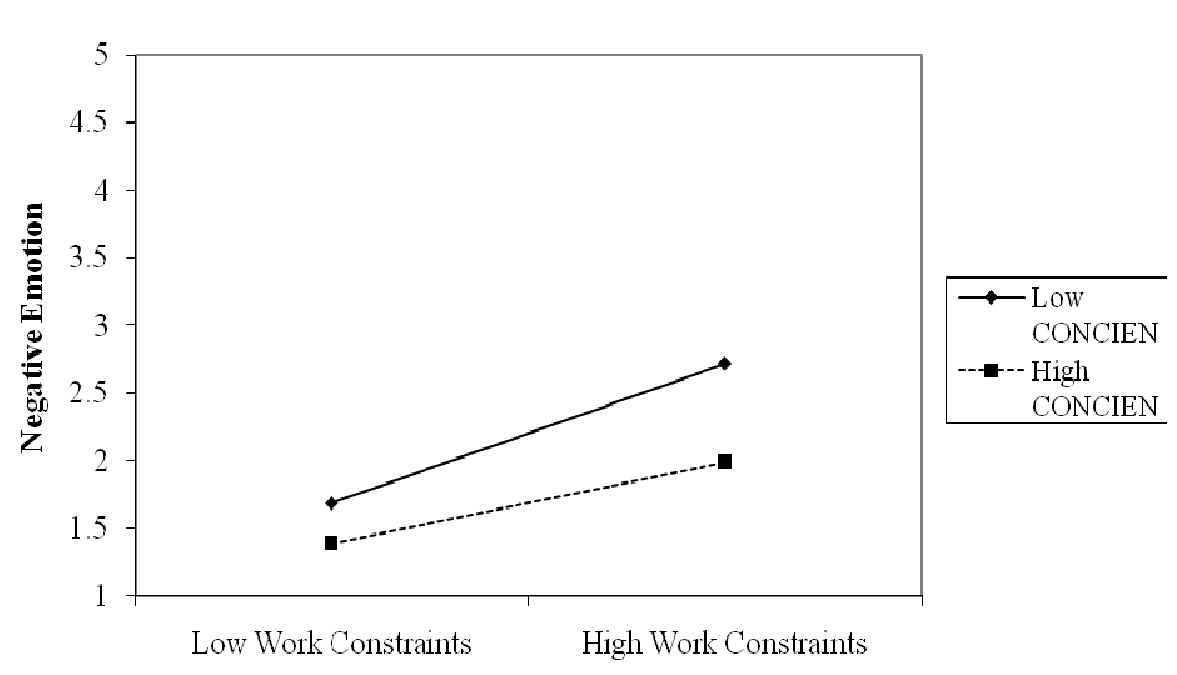

Figure 2. Conscientiousness (CONCIEN) moderates the Work Constraints - Negative Emotion Relation

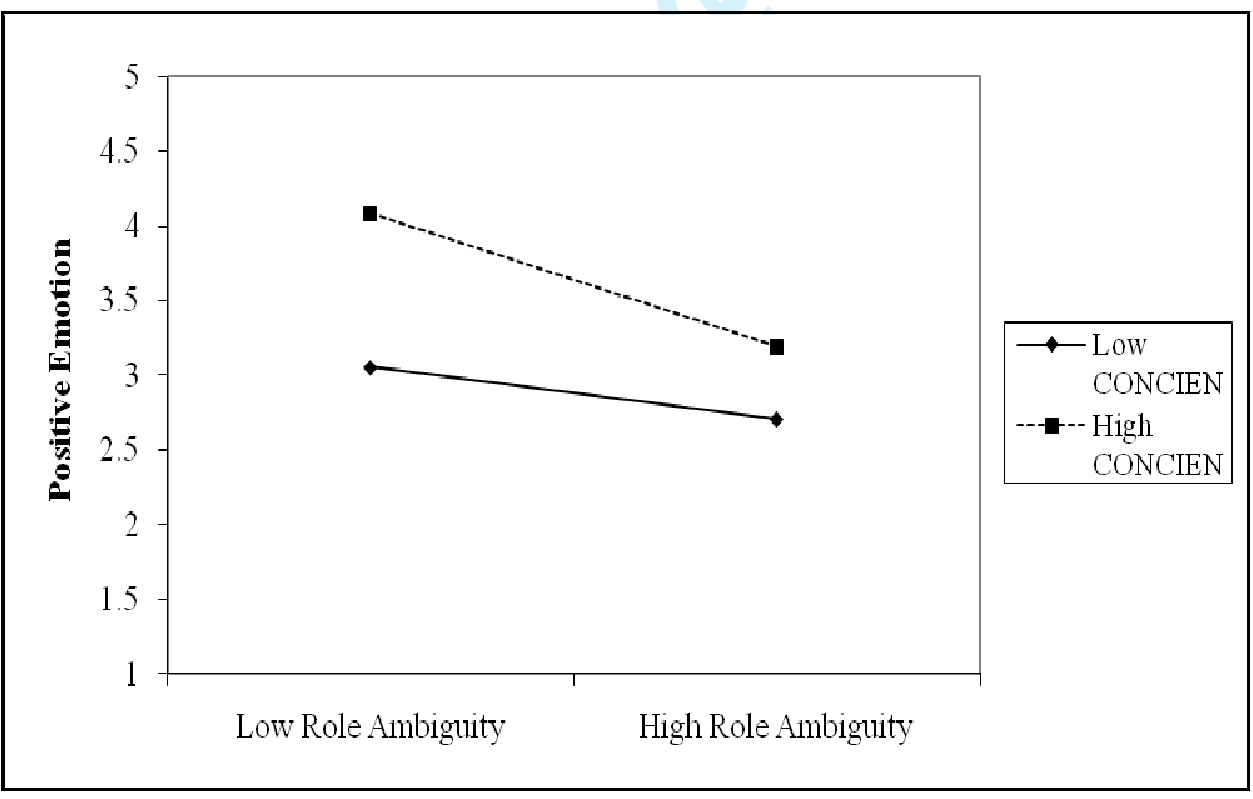

Figure 3. Conscientiousness (CONCIEN) moderates the Role Ambiguity -Positive Emotion Relation 